\title{
Staff Burnout in Care Institutions for Juvenile Delinquents in Jordan
}

\author{
Dr. Khaled Sulaiman Shhadeh Alsloot \\ Ministry of Social Development \\ Jordan \\ Email: khaledalsloud@yahoo.com
}

\begin{abstract}
Received: August 13, 2016 Accepted: September 19, 2016 Published: October 05, 2016
doi:10.5296/ijld.v6i3.10112 URL: http://dx.doi.org/10.5296/ ijld.v6i3. 10112
\end{abstract}

\begin{abstract}
The current study aimed to identify the levels of burnout among staff in care institutions for juvenile delinquents in Jordan, and how different these levels, based on the variables of academic qualifications, years of experience, and marital status. The sample consisted of (107) staff. Maslach Burnout Scale used in this study. The results showed high level of emotional exhaustion and depersonalization, and moderate level of lack of sense of accomplishment among participants. Level of emotional exhaustion varied according to academic qualifications: holders of secondary or below and university qualification holders, the results were in favor of holders of secondary or below, while no statistically significant differences shown in apathy and lack of sense of accomplishment and the total degree Burnout Scale. The results indicated no differences in the three main levels and the total degree of Burnout Scale based on the various levels of years of experience and marital status.
\end{abstract}

Keywords: Burnout, Staff of correctional institutions for juvenile delinquents, Jordan. 


\section{Introduction}

A lot of staff in the provision human care services face many of the psychological pressures of while they dot their tasks, as these obstacles are the result of the nature of the work they do, which requires them to interact directly with members of the community, among those staff are those who are working in the correctional institutions for juvenile delinquents, who are responsible for interacting with juvenile delinquents, and management of institutions sponsoring the juveniles, and their parents.

Burnout is a state of emotional, mental, and physical exhaustion caused by excessive and prolonged stress. It occurs when you feel overwhelmed and unable to meet constant demands.

Owing to much burdens faced by the staff in the care institutions of juvenile delinquents, this burden resulted in psychological stress, which reflected on their performance while carrying out the required tasks, which generates their burnout.

Freudenberger (1974) is considered the first to use the term "burnout", to refer to the physical emotional response to pressures of work among staff in humanitarian professions, who are striving for achieving their goals. The results shown in a study conducted by him on the psychological experiences as a result of his dealings and treatments with the referrals to his psychological clinic in New York City.

Cherniss (1980) defined burnout as a state of tension and anxiety that afflict the individual within the work environment, resulted in lack of individual commitment and neglect of the duties of the work. Maslach \& Jackson (1986) defined it as a state of the individual's loss of interest in those surrounding him at work, where the individual feels tired and emotionally exhausted which makes this individual loses the sense of accomplishment, and thus loses sympathy toward others. Schwarzer, Schmitz \& Tang (2000) defined burnout as a state of exhaustion and extreme fatigue as a result of psychological self-pressure within humanity service careers, and it is directly related to the feelings of individuals, whose careers require continuous and constant vulnerability to social situations replete with emotional feelings.

Maslach conceptualized burnout in three dimensional phenomenon, these are exhaustion, depersonalization and accomplishment. As a result of burnout individual's performance at work decreases and it causes damages in his health both physically and psychologically at behavioral level. The MBI Surveys address three general scales: Emotional Exhaustion measures feelings of being emotionally overextended and exhausted by one's work. Depersonalization measures an unfeeling and impersonal response toward recipients of one's service, care treatment, or instruction. Personal Accomplishment measures feelings of competence and successful achievement in one's work (Maslach\& Jackson, 1986; Maslach, Schaufeli \& Leiter, 2001; Maslach, 2003).

Psychological burnout afflicting the individual is accompanied by a range of physical and behavioral symptoms, representing in the low level of activity of the person, sleep disorder, headache, physical fatigue, chronic fatigue, as well as a sense of helplessness and guilt, not wanting to work, a tendency to violence and cruelty, constant change of work environment, in addition to lower positive self-view, the low level of feeling the sense of life and goals, the 
emergence of feelings of psychological alienation and despair, changing the system of values, and the convert of religious beliefs, and other symptoms (Lambie, 2007) .

Since the present study aims to identify burnout levels among staff in the care and correctional institutions of juvenile delinquents, many of the researchers emphasized that increasing the psychological pressure on the staff in the care institutions of juvenile delinquents and the inability to confront and overcome them can lead to a sense of psychological burnout. Kong (2005) found that the reasons behind social workers' vulnerability to psychological burnout as a result of their work with the children are due to the lack of recognition of their efforts they are making in their work, and long working hours, and the large number of the cases they are dealing with and their low salaries.

Tamim (2011) showed that females are more susceptible to emotional exhaustion and depersonalization than males, while the results showed no differences between males and females in the dimension of personal accomplishment, as well as the lack of differences in the dimensions of emotional exhaustion and lack of sense of accomplishment according to years of experience, while the most experienced staff are more depersonalized than those with lower years of experience, results indicated that all the dimensions of burnout among staff do not vary according to the quality of work.

Alderby (2012) found that the majority of burnout levels among workers in mental health care in humanitarian institutions, ranging from medium to high, and that the psychological burnout sources are emotional exhaustion, lack of the sense of accomplishment and depersonalization in order, and pointed out that males are more vulnerable to depersonalization than females, while it showed no differences between males and females in the dimensions of emotional exhaustion, and lack of sense of accomplishment, as well as the lack of differences in all burnout dimensions due to age, marital status, and type of service recipients, also the study indicated that any rise in monthly income causes an increase in the emotional exhaustion among staff.

McCarty (2013) revealed that police women working in correctional and rehabilitation institutions of juvenile delinquents are more likely to have symptoms of burnout than male police officers, and that psychological burnout sources among the police officers represented in lack of clarity of their role and relationship with colleagues and juniors. The study of Steinlin, Dolitzsch, Fischer, Schmeck, Fegrt \& Schmid (2015) aimed at detecting burnout level among workers in the institutions of reform and rehabilitation for juvenile delinquents and its relationship to job satisfaction, the study found that (18\%) of the sample showed high levels of burnout, and there was a negative correlation between job satisfaction and burnout among participants.

Salyers, Hood, Schwartz, Alexander, Aalsma (2015) showed that the majority of workers in delinquent centers pointed to the existence of a negative impact of psychological burnout on their professional expertise such as their inability to provide adequate services to delinquents, and their inability to deal adequately with the sources of psychological burnout.

White, Aaslma, Holloway, Adams \& Salyers (2015) showed that burnout level among 
workers in delinquent centers was high, and that burnout levels do not vary according to gender, age, academic qualifications and the race, and that the lack of job satisfaction and lack of clarity of professional roles were one of the most important prediction of burnout factors.

Jin, Sun, Jiang, Wang \& Wen (2016) demonstrated a negative correlation between self-autonomy and perception of procedural fairness and clarity of the professional roles of the workers in the reform and rehabilitation centers, and the presence of a positive correlation between the conflicts of professional roles and psychological and career pressures and dangerous work among workers in the reform and rehabilitation centers and Burnout they have, also indicated that male workers in the reform and rehabilitation centers are more vulnerable to psychological burnout than females.

The pieces of literature review mentioned earlier indicated the scarcity of studies that have investigated burnout among staff in the care institutions of juvenile delinquents, and that there is no study on this topic in the Jordanian environment, prompting the author of the current study to investigate this point to explore burnout levels among staff in the care and correctional institutions of juvenile delinquents, which is the objective of the current study.

\section{Statement of the Problem}

The present study is an attempt to detect the levels of burnout among staff in the care and correctional institutions of juvenile delinquents in Jordan, and it is designed to answer the following questions:

1. What are the frequencies' levels of the three dimensions of burnout among staff in the care institutions of juvenile delinquents in Jordan?

2. Do the frequencies' levels of the three dimensions of burnout among staff in the care institutions of juvenile delinquents in Jordan vary according to academic qualification?

3. Do the frequencies' levels of the three dimensions of burnout among staff in the care institutions of juvenile delinquents in Jordan vary according to years of experience?

4. Do the frequencies' levels of the three dimensions of burnout among staff in the care institutions of juvenile delinquents in Jordan vary according to marital status?

\section{Significance}

The significance of this study lies in the effective role played pay the participants in the construction, education and rehabilitation of juvenile delinquents, and to prepare them as good citizens. It also highlights the importance through the study of the phenomenon of burnout, which has an influence on the course of education and counseling and rehabilitation of juvenile delinquents, weakening the motivation of staff in this field for work and accomplishment, which draws the attention of officials in the care institutions of juvenile delinquents to identify the level of this negative phenomenon that make workers in the care institutions of juvenile delinquents to neglect their job and deal cruelly with juvenile 


\section{Macrothink}

delinquents, and indifferently with their coworkers; which is reflected on the work environment and productivity, which contributes to the development of plans, programs and methods that limit or reduce the appearance of this negative phenomenon, burnout, in the care institutions of juvenile delinquents in Jordan.

\section{Methodology and Procedures}

\subsection{Method \& variables}

The survey and descriptive method utilized in this study that aimed to identify the level of burnout among staff in the care institutions of juvenile delinquents in Jordan in light of academic qualifications, years of experience, and marital status.

\subsection{Sampling: participants}

The sample consisted of (132) staff in care institutions of juvenile delinquents in Jordan distributed to four care institutions for education and rehabilitation of juvenile delinquents in Jordan. Maslach and Jackson Burnout Scale applied to (25) participants of them for the purposes of verification of validity and reliability, and thus the instrument applied to (107) staff, and the sample distributed to a set of qualitative variables, as shown in Table (1) .

Table (1): The sample distribution based on demographic qualitative variables

\begin{tabular}{|l|l|l|l|}
\hline Variable & levels & No & Percentage \\
\hline $\begin{array}{l}\text { Academic } \\
\text { qualification }\end{array}$ & $\begin{array}{l}\text { Secondary } \\
\text { below }\end{array}$ & 31 & $28.9 \%$ \\
\hline & Diploma & 34 & $31.8 \%$ \\
\hline $\begin{array}{l}\text { Years } \\
\text { experience }\end{array}$ & University & 42 & $\% 39.3$ \\
\cline { 2 - 4 } & More than 5 years & 68 & $63.6 \%$ \\
\hline Marital status & Single & 46 & $43 \%$ \\
\cline { 2 - 4 } & Married & 61 & $57 \%$ \\
\hline Total & & 107 & $100 \%$ \\
\hline
\end{tabular}

\subsection{Scale}

Maslach\& Jackson Burnout Inventory utilized in this study (Maslach\& Jackson, 1981), which is composed of (22) paragraphs measuring symptoms of burnout in three dimensions: Emotional exhaustion (1-9), Depersonalization (10-14), and Personal accomplishment 


\section{Macrothink}

(15-22). The burnout scale was graded to seven degrees indicating frequency of feeling the same as Likert scale with a range of (0-6) degrees, where (not happening) was given (zero) while (repeated every day) was given (six degrees), so the degree of the individual in emotional exhaustion ranging from (0-54) degrees, in depersonalization ranging (0-30) degrees, and personal accomplishment (0-48) degrees, while the total score ranged between (0-132) degrees, the scale has been corrected according to the grading system of Maslach and Jackson, as shown in table (2):

Table (2): levels of dimensions of Maslash Burnout

\begin{tabular}{|l|l|l|l|}
\hline \multirow{2}{*}{ Dimension } & \multicolumn{3}{|l|}{ Level of burnout } \\
\cline { 2 - 4 } & Low & Moderate & High \\
\hline $\begin{array}{l}\text { Emotional } \\
\text { exhaustion }\end{array}$ & $\mathbf{1 7 - 0}$ & $\mathbf{2 9 - 1 8}$ & $\mathbf{3 0}$ \\
\hline $\begin{array}{l}\text { Depersonalization } \\
\text { Personal } \\
\text { accomplishment }\end{array}$ & $\mathbf{5 - 0}$ & $\mathbf{1 1 - 6}$ & $\mathbf{2 1 2}$ \\
\hline
\end{tabular}

Based on the results of table (2), getting high score on the dimensions of emotional exhaustion and Depersonalization means having a high burnout level, while a high degree of accomplishment means a low level of burnout.

\subsubsection{Validity}

The pieces of literature review such as the study of Maslach\& Jackson (1981), Ziyoudi (2007), and Aljaafarh, Badh, Al Khatib and Kharabsheh (2013) pointed to the high levels of validity of burnout scale. But, the author of the current study modified some paragraphs of the scale $(1,2,6,11,13,14,15,16,19$, and20) to suit the purpose and sampling of the study. Then, the scale validity and reliability have been verified through evaluating its first draft by a group of referees specialists in psychology, psychological counseling, and measurement and evaluation, who reported the appropriateness of the scale for measuring burnout among staff in care institutions of juvenile delinquents.

\subsubsection{Reliability}

The current study verified the reliability of the scale using internal consistency coefficient for each dimension of the scale using Cronbach's alpha for the scale dimensions and the total score, through applying the scale to a pilot sample of (25)staff working with juvenile delinquents in Jordan, from the same population, but not the same sample, where internal consistency coefficients for the emotional exhaustion was (0.82), depersonalization was (0.80), accomplishment (0.84), and total score (0.89). 


\section{$\triangle$ Macrothink}

\section{Results}

Results of the first question: What are the frequencies' levels of the three dimensions of burnout among staff in the care institutions of juvenile delinquents in Jordan? To answer this question, the arithmetic means and standard deviations utilized as shown in Table (3), which shows the means of the three dimensions of burnout: emotional exhaustion, depersonalization, and the lack of a sense of accomplishment, compared with the standards set by both Maslash and Jackson of the three levels (low, moderate, high), which have been pointed to in the correction procedures of the scale.

Table (3): The mean scores of the staff in the institutions of juvenile delinquents in Jordan based on the tripartite classification of levels of dimensions of Maslash burnout scale.

\begin{tabular}{|l|l|l|l|l|}
\hline Dimension & $\begin{array}{l}\text { Level of } \\
\text { burnout }\end{array}$ & standard & Score means & $\begin{array}{l}\text { Standard } \\
\text { deviations }\end{array}$ \\
\hline \multirow{2}{*}{$\begin{array}{l}\text { Emotional } \\
\text { exhaustion }\end{array}$} & low & $\mathbf{1 7 - 0}$ & & \\
\cline { 2 - 5 } & Moderate & $\mathbf{2 9 - 1 8}$ & & \\
\cline { 2 - 6 } & High & $\mathbf{2 3 0}$ & 36.52 & 11.403 \\
\hline \multirow{2}{*}{ Depersonalization } & low & $\mathbf{5 - 0}$ & & \\
\cline { 2 - 6 } & Moderate & $\mathbf{1 1 - 6}$ & & 6.522 \\
\cline { 2 - 6 } & High & $\mathbf{2 1 2}$ & 19.16 & \\
\hline \multirow{2}{*}{$\begin{array}{l}\text { Personal } \\
\text { accomplishment }\end{array}$} & low & $\mathbf{2 4 0}$ & & 4.973 \\
\cline { 2 - 6 } & Moderate & $\mathbf{3 9 - 3 4}$ & 37.76 & \\
\cline { 2 - 6 } & High & $\mathbf{5 3 3}$ & & \\
\hline
\end{tabular}

Table (3) showed that the score means of the current respondents indicate a high level of burnout on the dimensions of emotional exhaustion and depersonalization, and moderate level on personal accomplishment, according to the standard of Maslach in determining burnout level for each dimension in the scale.

Results of the second question: Do the frequencies'levels of the three dimensions of burnout among staff in the care institutions of juvenile delinquents in Jordan vary according to academic qualification? To answer this question, arithmetic means and standard deviations calculated as shown in table (4).

Table (4): Means and standard deviations for psychological burnout according to academic 
qualification

\begin{tabular}{|c|c|c|c|c|}
\hline Dimension & Levels & No. & Mean & St. D \\
\hline \multirow{4}{*}{$\begin{array}{l}\text { Emotional } \\
\text { exhaustion }\end{array}$} & Secondary and below & 31 & 41.19 & 8.616 \\
\hline & Diploma & 34 & 34.59 & 12.295 \\
\hline & University & 42 & 34.64 & 11.703 \\
\hline & Total & 107 & 36.52 & 11.403 \\
\hline \multirow[t]{4}{*}{ Depersonalization } & Secondary and below & 31 & 18.45 & 6.932 \\
\hline & Diploma & 34 & 19.24 & 6.315 \\
\hline & University & 42 & 19.62 & 6.488 \\
\hline & Total & 107 & 19.16 & 6.522 \\
\hline \multirow{4}{*}{$\begin{array}{l}\text { Personal } \\
\text { accomplishment }\end{array}$} & Secondary and below & 31 & 38.10 & 5.534 \\
\hline & Diploma & 34 & 38.24 & 4.645 \\
\hline & University & 42 & 37.12 & 4.845 \\
\hline & Total & 107 & 37.76 & 4.973 \\
\hline \multirow[t]{4}{*}{ Total score } & Secondary and below & 31 & 101.97 & 11.164 \\
\hline & Diploma & 34 & 97.41 & 14.951 \\
\hline & University & 42 & 97.45 & 15.678 \\
\hline & Total & 107 & 98.75 & 14.290 \\
\hline
\end{tabular}

Table (4) showed differences in the means of the three groups; and to indicate significance of differences between these groups, one-way analysis of variance utilizedto show the differences between the three levels of academic qualification in the means of the three dimensions and the total burnout scale, as shown in table (5).

Table (5): Results of the analysis of one-way variance of the differences in burnout levels 
based on the academic qualification

\begin{tabular}{|c|c|c|c|c|c|c|}
\hline Dimension & $\begin{array}{l}\text { Source of } \\
\text { variance }\end{array}$ & $\begin{array}{l}\text { Sum of } \\
\text { squares }\end{array}$ & $\begin{array}{l}\text { Degre } \\
\text { es of } \\
\text { freedo } \\
m\end{array}$ & $\begin{array}{ll}\text { Mean of } \\
\text { sum } & \text { of } \\
\text { squares } & \end{array}$ & $\begin{array}{l}\text { F-valu } \\
\text { e }\end{array}$ & $\begin{array}{l}\text { Significanc } \\
\text { e level }\end{array}$ \\
\hline \multirow[t]{2}{*}{$\begin{array}{l}\text { Emotional } \\
\text { exhaustion }\end{array}$} & $\begin{array}{l}\text { Between } \\
\text { groups }\end{array}$ & 951.975 & 2 & 475.987 & 3.858 & .024 \\
\hline & $\begin{array}{l}\text { Within } \\
\text { groups }\end{array}$ & $\begin{array}{l}12830.71 \\
7\end{array}$ & 104 & 123.372 & & \\
\hline \multirow[t]{2}{*}{ Depersonalization } & $\begin{array}{l}\text { Between } \\
\text { groups }\end{array}$ & 24.599 & 2 & 12.300 & .285 & .752 \\
\hline & $\begin{array}{l}\text { Within } \\
\text { groups }\end{array}$ & 4483.700 & 104 & 43.112 & & \\
\hline \multirow[t]{2}{*}{$\begin{array}{l}\text { Personal } \\
\text { accomplishment }\end{array}$} & $\begin{array}{l}\text { Between } \\
\text { groups }\end{array}$ & 28.450 & 2 & 14.225 & .570 & .567 \\
\hline & $\begin{array}{l}\text { Within } \\
\text { groups }\end{array}$ & 2593.232 & 104 & 24.935 & & \\
\hline \multirow[t]{2}{*}{ Total } & $\begin{array}{l}\text { Between } \\
\text { groups }\end{array}$ & 452.579 & 2 & 226.290 & 1.110 & .333 \\
\hline & $\begin{array}{l}\text { Within } \\
\text { groups }\end{array}$ & $\begin{array}{l}21193.60 \\
8\end{array}$ & 104 & 203.785 & & \\
\hline
\end{tabular}

Table (5) indicated that there were statistically significant differences due to academic qualification in the dimension of emotional exhaustion, while it showed no statistically significant differences in depersonalization and personal accomplishment and the total score of psychological burnout. Scheffé's method conducted to find out sources of differences in emotional exhaustion, and the results of this test illustrated in table (6). 
Table (6): Scheffé Test results for academic qualification

\begin{tabular}{|l|l|l|l|l|l|}
\hline Dimension & $\begin{array}{l}\text { Square } \\
\text { differences }\end{array}$ & Mean & $\begin{array}{l}\text { Secondary } \\
\text { and below }\end{array}$ & Diploma & University \\
\hline $\begin{array}{l}\text { Emotional } \\
\text { exhaustion }\end{array}$ & $\begin{array}{l}\text { Secondary } \\
\text { and below }\end{array}$ & 41.19 & & & \\
\cline { 2 - 6 } & Diploma & 34.59 & 6.61 & & \\
\cline { 2 - 6 } & University & 34.64 & $6.55 *$ & -.05 & \\
\hline
\end{tabular}

Table (6) conveyed that the source statistically significant differences in the means of emotional exhaustion is due to the differences between the two groups of staff holding "secondary and below" and "university qualification", in favor of the staff holding "secondary qualification and below".

Results of the third question: Do the frequencies' levels of the three dimensions of burnout among staff in the care institutions of juvenile delinquents in Jordan vary according to years of experience? T-test conducted to determine the differences between the means and standard deviations for those working in the care institutions of juvenile in each of the levels of years of experience (five years or less, and more than 5 years) in the three dimensions and the total score of burnout as shown in table (7).

Table (7): T-Test results of the differences between the means and standard deviations, based on years of experience in the three dimensions and the total score of burnout

\begin{tabular}{|c|c|c|c|c|c|c|c|}
\hline Dimension & $\begin{array}{l}\text { Years of } \\
\text { experience }\end{array}$ & No. & Mean & St. D & T-value & $\begin{array}{l}\text { Degrees } \\
\text { of } \\
\text { freedom }\end{array}$ & $\begin{array}{l}\text { Sig. } \\
\text { level }\end{array}$ \\
\hline \multirow{2}{*}{$\begin{array}{l}\text { Emotional } \\
\text { exhaustion }\end{array}$} & $\leq 5$ & 39 & 36.90 & 11.550 & \multirow{2}{*}{.256} & \multirow{2}{*}{105} & \multirow{2}{*}{.799} \\
\hline & $>5$ & 68 & 36.31 & 11.398 & & & \\
\hline \multirow[t]{2}{*}{ Depersonalization } & $\leq 5$ & 39 & 18.26 & 6.402 & \multirow{2}{*}{-1.085} & \multirow{2}{*}{105} & \multirow{2}{*}{.280} \\
\hline & $>5$ & 68 & 19.68 & 6.580 & & & \\
\hline \multirow{2}{*}{$\begin{array}{l}\text { Personal } \\
\text { accomplishment }\end{array}$} & $\leq 5$ & 39 & 37.92 & 4.965 & \multirow{2}{*}{.260} & \multirow{2}{*}{105} & \multirow{2}{*}{.795} \\
\hline & $>5$ & 68 & 37.66 & 5.012 & & & \\
\hline Total & $\leq 5$ & 39 & 97.95 & 15.516 & -.436 & 105 & .664 \\
\hline
\end{tabular}




\begin{tabular}{|l|l|l|l|l|l|l|l|}
\hline & $>5$ & 68 & 99.21 & 13.637 & & & \\
\hline
\end{tabular}

Table (7) showed lack of statistically significant differences at the level of less than (0.05) in the three dimensions (emotional exhaustion, depersonalization, and personal sense of accomplishment) and the total score of burnout according to years of experience.

Results of the fourth question: Do the frequencies' levels of the three dimensions of burnout among staff in the care institutions of juvenile delinquents in Jordan vary according to marital status? T-test conducted to determine the differences between the means and standard deviations for those working in care institutions for juvenile delinquents based on marital status (single and married) in the three dimensions and the total score of burnout, as shown in table (8).

Table (8): T-Test results for the differences between the means and standard deviations, based on the marital status in the three dimensions and the total score of burnout

\begin{tabular}{|c|c|c|c|c|c|c|c|}
\hline Dimension & $\begin{array}{l}\text { Marital } \\
\text { status }\end{array}$ & No & Mean & St. D & T-value & $\begin{array}{l}\text { Degrees } \\
\text { of } \\
\text { freedom }\end{array}$ & $\begin{array}{l}\text { Sig. } \\
\text { level }\end{array}$ \\
\hline \multirow{2}{*}{$\begin{array}{l}\text { Emotional } \\
\text { exhaustion }\end{array}$} & Single & 46 & 34.13 & 11.796 & \multirow{2}{*}{-1.908} & \multirow{2}{*}{105} & \multirow{2}{*}{.059} \\
\hline & Maried & 61 & 38.33 & 10.847 & & & \\
\hline \multirow[t]{2}{*}{ Depersonalization } & Single & 46 & 20.07 & 6.923 & \multirow{2}{*}{1.252} & \multirow{2}{*}{105} & \multirow{2}{*}{.213} \\
\hline & Maried & 61 & 18.48 & 6.171 & & & \\
\hline \multirow{2}{*}{$\begin{array}{l}\text { Personal } \\
\text { accomplishment }\end{array}$} & Single & 46 & 37.74 & 5.511 & \multirow{2}{*}{-.032} & \multirow{2}{*}{105} & \multirow{2}{*}{.974} \\
\hline & Maried & 61 & 37.77 & 4.573 & & & \\
\hline \multirow[t]{2}{*}{ Total } & Single & 46 & 96.85 & 15.958 & \multirow{2}{*}{-1.197} & \multirow{2}{*}{105} & \multirow{2}{*}{.234} \\
\hline & Maried & 61 & 100.18 & 12.842 & & & \\
\hline
\end{tabular}

Table (8) showed no statistically significant differences at the level of less than (0.05) in the three dimensions (emotional exhaustion, depersonalization, and personal accomplishment) and the total score of burnout based on marital status.

\section{Discussion}

The results of the current study showed that the staffs, who were working in the care institutions of juvenile delinquents in Jordan, suffer from a high level of emotional exhaustion and depersonalization, and a moderate level of personal accomplishment 
according to Maslach Burnout Scale. The result of the current study is consistent with Alderby (2012), which found that most of the burnout levels among workers in mental health care in humanitarian institutions, ranging from moderate to high, and the study of Steinlin, et al. (2015), which found that (18\%) of the workers in care institutions for the reform and rehabilitation of juvenile delinquents showed high levels of burnout, the study of White, et al. (2015) also found that the level of burnout among workers in care centers of juvenile delinquents was high.

Kong (2005) explained the reasons behind the rise in the level of emotional exhaustion and depersonalization, and the moderate level of personal accomplishment among the workers in care centers for children to the lack of recognition for their efforts they are making in their work, long working hours, the difficulty they face in dealing with the cases, and the low salaries. This result can also be attributed to dissatisfaction of workers in institutions of the juvenile delinquents with their work and lack of clarity of professional roles assigned to them.

The study also resulted in statistically significant differences in the means of the dimension of emotional exhaustion due to academic qualification variable, between the two categories of workers holding secondary certificate or below and university qualification, and in favor of those holding secondary or below. This finding emphasizes the importance of recruiting holders of special qualifications in the care institutions of juvenile delinquents who hold professional qualifications in the field of dealing with juvenile delinquents, and indicating a low level of emotional exhaustion among holders of university qualifications, compared with holders of secondary qualification or below. University qualification provides its holders with information that may help them understand the nature of juvenile delinquents who are dealing with them, in addition to giving them many of the skills on how to deal with this group and guide them and modify their behavior; which would enable them to face the problems and difficulties involved in the work with juvenile delinquents and thus reduces the level of sense of emotional exhaustion. This result differed from the result of White, et al. (2015) that disclosed that the emotional exhaustion levels do not vary based on the various levels of academic qualifications.

The results also showed no statistically significant differences in the three dimensions (emotional exhaustion, depersonalization, and personal accomplishment) and the total score of burnout levels according to years of experience. This result is consistent with the findings of Tamim (2011), which refers to the lack of differences in the dimensions of emotional exhaustion and lack of sense of accomplishment according to years of experience, while it differed with Tamim (2011) that suggests that the most experienced workers are more depersonalized than those with less years of experience. This finding may be due to the similarity of professional and psychological pressures faced by workers in the care institutions of juvenile delinquents, which have the weight to raise the symptoms of burnout among its staff, and prevent their adaptation to the difficulties and burdens of their profession despite the enjoyment of some professional experience supposed to be one of the factors that help them cope with the symptoms of burnout effectively. 


\section{I Macrothink}

International Journal of Learning and Development

ISSN 2164-4063

2016, Vol. 6, No. 3

The study also found that there were no statistically significant differences in the three dimensions (emotional exhaustion, depersonalization, and personal accomplishment) and the total score of burnout between married and single workers. This result is consistent with the findings of Alderby (2012), which showed no differences in all dimensions of burnout due to marital status. This result can be explained in the light of the similarity of the environmental and social conditions that are related to the nature of the work, and the nature of the problems and difficulties faced by those who are working with juvenile delinquents.

\section{Recommendations}

In light of the results of the current study, the following recommendations made by the author:

1. Improving the working conditions for teachers and specialists working with juvenile delinquents in order to alleviate the emotional exhaustion and depersonalization they have, and burnout in general.

2. Sensitizing workers in care institutions for juvenile delinquents of the characteristics of this group and their needs and how to deal with them and help them, in order to raise their sense of the importance of their work assigned to them.

3. Intensifying of training workshops and rehabilitative courses needed by staff working with juvenile delinquents so that they can carry out their professional duties to the fullest.

4. The need to intensify studies dealing with burnout among this segment of workers, and to study its relationship to other social variables such as subsidies, and social and psychological compatibility.

\section{References}

Alderby, S. (2012). Levels and the sources of burnout among workers in the field of mental health care in humanitarian institutions in Oman and its relationship to complereness and some demographic variables. Unpublished MA Thesis. Jordan: University of Jordan.

Aljaafarh, A., Badh, A., AlKhatib, B., AlKharabsheh, O. (2013). Burnout among university students living in University housing and its relationship to a number of variables.Journal Islamic University of Educational and Psychological Studies, 21 (1): 295-325.

Cherniss, C. (1980). Staff burnout: job stress in the human service. Beverly Hills, CA: Sage Publication lnc.

Freudenberger, H.J (1974). Staff burnout.Journal of Social Issues. (1): 159-165.

Jin, X., Sun, I., Jiang, Sh., Wang, Y \& Wen, Sh (2016). The Impact of Job Characteristics on Burnout Among Chinese Correctional Workers. International Journal of Offender Therapy and Comparative Criminology.http://ijo.sagepub.com/content/early/2016/05/04/0306624X16648419. 


\section{Macrothink}

International Journal of Learning and Development

ISSN 2164-4063

2016, Vol. 6, No. 3

Kong, G. (2005). Factors associated with burnout at Korean child protective service workers. Korean journal of Family Welfare, 10 (3): 83-103.

Lambie, G.M (2007). The Contribution of Ego Development Level to Burnout IN School Counselors: Implications for Professional School Counseling. Journal of Counseling \& Development. 85: 82-88.

Maslach, C.(2003). Job Burnout: New Directions in Research and Intervention, Current Directions in Psychological Science, 12(5):189-192.

Maslach, C., \& Jackson, S. (1986). Maslach Burnout Inventory Manual (2nd ed.). Palo Alto, CA: Consulting psychologists Press.

Maslach, C., Schaufeli, W., \&Leiter, M .(2001). Job Burnout.An-nual Review of Psychology, 52: $397-422$.

Maslach. C., \&Jackon, S. (1981). The measurement of experienced burnout.Journal of Occupational Behavior,2: 99-113.

McCarty, W. (2013).Gender differences in burnout among municipal police sergeants, Policing, 36(4): 803-818.

Salyers, M., Hood, B., Schwartz, K., Alexander, A \& Aalsma, M. (2015). The Experience, Impact, and Management of Professional Burnout among Probation Officers in Juvenile Justice Settings, Pediatric Adolescent Health, 54(3): 175-193.

Schwarzer, R., Schmitz, G., \& Tang, C.(2000). Teacher Burnout in Hong Kong and Germany; Across Cultural Validation of the Maslach Burnout Inventory, Anxiety, Stress and Coping, 13(3): 36-52.

Steinlin, C., Dölitzsch, C., Fischer, S., Schmeck, K., Fegert, J.M\&Schmid, M. (2015). The Relationship Between Burnout Symptoms and Work Satisfaction Among Child Welfare Workers in Residential Care, PraxKinderpsycholKinderpsychiatr, 65 (3): 162-80.

Tamim, I. (2011). The relationship between burnout and emotional intelligence among workers in social care.Unpublished MA Thesis. Syria: University of Damascus.

White, L., Aalsma, M., Holloway, E., Adams, E \&Salyers, M (2015). Job-related burnout among juvenile probation officers: Implications for mental health stigma and competency, Psychological Services, 12(3): 291-302.

Ziyoudi, M. (2007).Sources of psychological stress and Burnout among special education teachers in Karak governorate and its relationship with some variables.Journal of Damascus University, 23 (2), pp. 189 to 219. 


\section{Macrothink}

International Journal of Learning and Development

ISSN 2164-4063

\section{Copyright Disclaimer}

Copyright for this article is retained by the author(s), with first publication rights granted to the journal.

This is an open-access article distributed under the terms and conditions of the Creative Commons Attribution license (http://creativecommons.org/licenses/by/3.0/). 